\title{
Knowledge on SRI (System of Rice Intensification) of Farmers in Tripura, India
}

\author{
Dipak Nath $^{1^{*}}$ and D.K. Das ${ }^{2}$ \\ ${ }^{1}$ KVK, Khowai (Tripura), India \\ ${ }^{2}$ DDA, Dept. of Agriculture, Govt. of Tripura, India \\ *Corresponding author
}

\section{A B S T R A C T}

\begin{tabular}{|c|}
\hline Keywords \\
\hline $\begin{array}{l}\text { Knowledge, } \\
\text { Tripura, Rice and } \\
\text { SRI }\end{array}$ \\
\hline Article Info \\
\hline $\begin{array}{l}\text { Accepted: } \\
28 \text { February } 2018 \\
\text { Available Online } \\
\text { 10 March } 2018\end{array}$ \\
\hline
\end{tabular}

The study was carried out in the two district of Tripura, viz., West Tripura and South Tripura with randomly selected 200 rice farmers from purposively selected 4 blocks of the districts. The State of Tripura is located between $22^{\circ} 56^{\prime \prime}$ and $24^{\circ} 32^{\prime \prime}$ North latitude and between $90^{\circ} 09^{\prime \prime}$ and $92^{\circ} 20^{\prime \prime}$ East latitude. Tripura is a landlocked State. System of Rice Intensification (SRI) method of paddy cultivation is important because it needs less seed, less water, less fertilizer and less attack of pest $\&$ disease but per hectare yield gain is more than traditional method of paddy cultivation. Rice is the major food crop in Tripura with 75 per cent of its cropped area devoted to the production of rice (Department of Agriculture, Govt. of Tripura). In terms of production it ranks next to Assam in North East states. In Tripura state as a whole a large section of the SRI farmers possessed knowledge high to medium level (39.5\% to $35.0 \%$ ) on SRI technology.

\section{Introduction}

Tripura is a state in North-East India which borders Bangladesh, Mizoram and Assam. It is surrounded by Bangladesh on its north, south and west. It shares a $53 \mathrm{~km}$ long border with Assam and $109 \mathrm{~km}$ long border with Mizoram. The State of Tripura is located between $22^{\circ}$ $56^{\prime \prime}$ and $24^{\circ} 32^{\prime}$ "North latitude and between $90^{\circ} 09^{\prime \prime}$ and $92^{\circ} 20^{\prime \prime}$ East latitude. Tripura is a landlocked State.

The System of Rice Intensification (SRI) methodology was synthesized in the early 1980s by Fr. Henri de Laulanié, S.J., who came to Madagascar from France in 1961 and spent the next (and last) 34 years of his life working with Malagasy farmers to improve their agricultural systems, and particularly their rice production, since rice is the staple food in Madagascar. SRI was developed by Father Henry de Laulanie who was striving to improve the lively hood of the poor rice farmers of Madagascar. SRI method of paddy cultivation is important because it needs less seed, less water, less fertilizer and less attack of pest and disease but per hectare yield gain is more than traditional method of paddy cultivation. Rice is the major food crop in Tripura with 75 per cent of its cropped area devoted to the production of rice. In terms of production it ranks next to Assam in North 
East states. Despite all the rich profitability of the technology of system of rice intensification (SRI) practices the extent of its spread has still remained insignificant due to various reasons. The present study has been designed to investigate some factors which closely related with the knowledge and the adoption behaviour of rice farmers towards SRI, so that the knowledge could be used in rapid diffusion of the system of rice intensification technology to the rice farmers.

\section{Materials and Methods}

The present study was carried out in two districts viz., West Tripura and South Tripura district of Tripura. The two districts were selected purposively in view of the diverse land and agriculture resources ideally suited for taking up SRI technology and they have been situated in different agro ecological zones with minimum variation. Among seventeen development blocks in West Tripura district two blocks namely Jirania and Bishalgarh and eleven development blocks in South Tripura district two blocks namely Matabari and Bokafa were selected purposively for the study. From each block, five villages were selected with the help of a random number table following the method of simple random sampling. In total ten villages of each district are served as the representing unit for this study. A simple random sampling technique were followed in the selection of total 200 number of respondents, 100 respondents from each district, 50 respondents from each block and 10 respondents from each village for the final data collection. Total sample size is 200, of which 100 from each district.

In this study, knowledge refers to the body of information understood and retained by the respondents about system of rice intensification technology which comprises various improved method of rice cultivation and management practices for increased rice production from a unit area of land. For the purpose of the present investigation, a teacher made knowledge test was designed to measure the knowledge of the respondents about the SRI technology. The knowledge test consisted of 40 items covering different aspects of composite rice cultivation practices, with required management skills. All the items were objective type and the 'one score was given for the "correct response" and 'zero' for "wrong response". The summation of scores for the 'yes' responses over all the items for a particular respondent indicated his extent of knowledge. The maximum and the minimum score would be forty and zero respectively. Further, the raw knowledge score of each individual respondent was converted into a knowledge index, using the formula.

Number of correct responses Knowledge Index $(\mathrm{Kl})=$ Total number of knowledge items

Thus, after computing knowledge index scores, the respondents were categorized into three categories taking mean and standard deviation as a measure of check. The knowledge level was measured in two aspects, viz., overall knowledge level of rice farmers and knowledge level of rice farmer regarding specific aspects of practices recommended for SRI practices.

\section{Results and Discussion}

Knowledge level of rice farmers regarding System of Rice Intensification (SRI) practices

\section{Overall knowledge level of rice farmers}

\section{West Tripura}

As regards the knowledge level of rice farmers about SRI practices, it is found that out of 100 
rice farmers most of the rice farmers i.e., 39 (39.0\%) have high level of knowledge whereas $36(36.0 \%)$ have a medium level of knowledge, followed by $25(25.0 \%)$ with a low level of knowledge.

\section{South Tripura}

As regards their knowledge level about SRI practices, it is found that out of 100 rice farmers the majority of rice farmers i.e., $40(40.0 \%)$ have high level of knowledge whereas $34(34.0 \%)$ have medium level of knowledge, followed by $26(26.0 \%)$ with a low level of knowledge.

\section{Tripura}

As regards their knowledge level about SRI practices, it is found that out of 100 rice farmers, majority of rice farmers i.e., 79 $(39.5 \%)$ have high level of knowledge, whereas $70(35.0 \%)$ have medium level of knowledge, followed by $51(25.5 \%)$ with a low level of knowledge.

Data presented in Table 1 reveals that the majority of the rice farmers have high to medium level of knowledge regarding SRI practices in the state of Tripura. Scientific knowledge of any technology is an essential prerequisite for increased productivity. The present findings are in conformity with the findings of Beerannavar (1995), Mahandra Kumar (1996) and Meti (1998).

Knowledge level of rice farmer regarding specific aspects of practices recommended for SRI practices

\section{West Tripura}

The Table 2 indicates that a more or less high percentage of rice farmers have precise knowledge on the principle of SRI in such vital matters or item as SRI method is followed in (paddy cultivation/vegetable cultivation) (100\%); SRI method of cultivation requires (more / less seed) $(100 \%)$; Age of the seedling should be $(8-12 / 15-20$ days)(100\%); Per hectare seed requirement is $(5 \mathrm{~kg} / 15-20 \mathrm{~kg})(100 \%)$; In SRI method followed (line sowing/traditional sowing) (100\%); Depth of sowing (effect tillering/ flowering) (100\%); Transplanting must be in SRI method (shallow/deep) (100\%) (Fig. 1).

Table.1 Distribution of respondents according to knowledge level (N=200)

\begin{tabular}{|l|c|c|c|c|c|c|}
\hline \multicolumn{1}{|l|}{ Category } & \multicolumn{2}{|c|}{ West Tripura $(\mathbf{n = 1 0 0})$} & \multicolumn{2}{|c|}{ South Tripura $(\mathbf{n = 1 0 0})$} & \multicolumn{2}{|c|}{ Tripura (N= 200) } \\
\hline & Frequency & $\%$ & Frequency & \% & Frequency & $\%$ \\
\hline Low & 25 & 25 & 26 & 26 & 51 & 25.5 \\
\hline Medium & 36 & 36 & 34 & 34 & 70 & 35.0 \\
\hline High & 39 & 39 & 40 & 40 & 79 & 39.5 \\
\hline
\end{tabular}


Table.2 Knowledge level of rice farmers regarding specific items of recommended System of Rice Intensification (SRI) practices $(\mathrm{N}=200)$

\begin{tabular}{|c|c|c|c|c|c|c|c|}
\hline \multirow[t]{3}{*}{ SN } & \multirow[t]{3}{*}{ Practices } & \multicolumn{6}{|c|}{ Response Category } \\
\hline & & \multicolumn{2}{|c|}{$\begin{array}{l}\text { West Tripura } \\
\quad(n=100)\end{array}$} & \multicolumn{2}{|c|}{$\begin{array}{l}\text { South Tripura } \\
(\mathrm{n}=100)\end{array}$} & \multicolumn{2}{|c|}{$\begin{array}{r}\text { Tripura } \\
(\mathbf{N}=\mathbf{2 0 0})\end{array}$} \\
\hline & & $\mathbf{F}$ & $\%$ & $\mathbf{F}$ & $\%$ & $\mathbf{F}$ & $\%$ \\
\hline 1 & $\begin{array}{l}\text { SRI method is followed in (paddy } \\
\text { cultivation/vegetable cultivation) }\end{array}$ & 100 & 100 & 99 & 99 & 199 & 99.5 \\
\hline 2 & $\begin{array}{l}\text { SRI method of cultivation requires (more / } \\
\text { less seed) }\end{array}$ & 100 & 100 & 100 & 100 & 200 & 100 \\
\hline 3 & $\begin{array}{l}\text { Requirement of water in SRI method } \\
\text { (more/less) }\end{array}$ & 96 & 96 & 92 & 92 & 188 & 94 \\
\hline 4 & $\begin{array}{l}\text { SRI method of paddy cultivation is costly } \\
\text { (Yes/No) }\end{array}$ & 69 & 69 & 55 & 55 & 124 & 62 \\
\hline 5 & $\begin{array}{l}\text { In SRI method no chemical fertilizer is } \\
\text { required (Yes/No) }\end{array}$ & 79 & 79 & 58 & 58 & 137 & 68.5 \\
\hline 6 & $\begin{array}{l}\text { Requirement of manures \& fertilizers is } \\
\text { more }(\text { Yes/No) }\end{array}$ & 65 & 65 & 46 & 46 & 111 & 55.5 \\
\hline 7 & $\begin{array}{l}\text { In SRI method only organic fertilizer is } \\
\text { applied (Yes/No) }\end{array}$ & 97 & 97 & 83 & 83 & 180 & 90 \\
\hline 8 & $\begin{array}{l}\text { Seedling raising requires in SRI } \\
\text { method(more care/less care) }\end{array}$ & 87 & 87 & 91 & 91 & 178 & 89 \\
\hline 9 & $\begin{array}{l}\text { Assured irrigation is required in SRI } \\
\text { method (Yes/No) }\end{array}$ & 77 & 77 & 80 & 80 & 157 & 78.5 \\
\hline 10 & $\begin{array}{l}\text { In SRI method weed infestation is more } \\
\text { (Yes/No) }\end{array}$ & 58 & 58 & 81 & 81 & 139 & 69.5 \\
\hline 11 & $\begin{array}{l}\text { In SRI method good drainage facility is } \\
\text { not required (True/False) }\end{array}$ & 88 & 88 & 77 & 77 & 165 & 82.5 \\
\hline 12 & $\begin{array}{l}\text { SRI method of paddy cultivation is variety } \\
\text { neutral (True/False) }\end{array}$ & 90 & 90 & 87 & 87 & 177 & 88.5 \\
\hline 13 & $\begin{array}{l}\text { Bio-fertilizer application is helpful } \\
\text { (True/False) }\end{array}$ & 96 & 96 & 90 & 90 & 186 & 93 \\
\hline 14 & $\begin{array}{l}\text { In this method yield increases minimum } \\
1 / 3 \text { rd than traditional. (True/False) }\end{array}$ & 55 & 55 & 88 & 88 & 143 & 71.5 \\
\hline 15 & $\begin{array}{l}\text { Timely availability of labour is one of the } \\
\text { problem (Yes/No) }\end{array}$ & 100 & 100 & 88 & 88 & 188 & 94 \\
\hline 16 & $\begin{array}{l}\text { It requires more labour than traditional } \\
\text { (Yes/No) }\end{array}$ & 53 & 53 & 48 & 48 & 101 & 50.5 \\
\hline 17 & $\begin{array}{l}\text { Seedling requirement per hill more than } \\
\text { one (True/False) }\end{array}$ & 90 & 90 & 79 & 79 & 169 & 84.5 \\
\hline 18 & $\begin{array}{l}\text { Age of the seedling is more than } \\
\text { traditional method (Yes/No) }\end{array}$ & 99 & 99 & 87 & 87 & 186 & 93 \\
\hline 19 & $\begin{array}{l}\text { Age of the seedling should be (8-12/15-20 } \\
\text { days) }\end{array}$ & 100 & 100 & 97 & 97 & 197 & 98.5 \\
\hline
\end{tabular}




\begin{tabular}{|c|c|c|c|c|c|c|c|}
\hline 20 & $\begin{array}{l}\text { Per Hectare seed requirement is }(5 \mathrm{~kg} / 15- \\
20 \mathrm{~kg})\end{array}$ & 100 & 100 & 98 & 98 & 198 & 99 \\
\hline 21 & $\begin{array}{l}\text { Traditional farmers are not fit for SRI } \\
\text { method (true/false) }\end{array}$ & 82 & 82 & 60 & 60 & 142 & 71 \\
\hline 22 & $\begin{array}{l}\text { Water management is one of important } \\
\text { factor(True/False) }\end{array}$ & 95 & 95 & 88 & 88 & 183 & 91.5 \\
\hline 23 & $\begin{array}{l}\text { Disease and pest attack is more in this } \\
\text { method (True/False) }\end{array}$ & 86 & 86 & 68 & 68 & 154 & 77 \\
\hline 24 & $\begin{array}{l}\text { SRI method requires very fertile soil } \\
\text { (True/False) }\end{array}$ & 75 & 75 & 64 & 64 & 139 & 69.5 \\
\hline 25 & $\begin{array}{l}\text { In SRI method followed (line } \\
\text { sowing/traditional sowing) }\end{array}$ & 100 & 100 & 95 & 95 & 195 & 97.5 \\
\hline 26 & $\begin{array}{l}\text { Depth of sowing (effect } \\
\text { tillering/flowering) }\end{array}$ & 100 & 100 & 96 & 96 & 196 & 98 \\
\hline 27 & $\begin{array}{l}\text { All types of paddy soil not fit for SRI } \\
\text { (Yes/No) }\end{array}$ & 77 & 77 & 76 & 76 & 163 & 81.5 \\
\hline 28 & Cost benefit ratio is high (Yes/ No) & 60 & 60 & 82 & 82 & 142 & 71 \\
\hline 29 & $\begin{array}{l}\text { Standing water interfere crop growth and } \\
\text { tillering(Yes/ No) }\end{array}$ & 83 & 83 & 79 & 79 & 162 & 81 \\
\hline 30 & $\begin{array}{l}\text { Transplanting must be in SRI method } \\
\text { (shallow/deep) }\end{array}$ & 100 & 100 & 98 & 98 & 198 & 99 \\
\hline 31 & $\begin{array}{l}\text { Not much care is required in uprooting } \\
\text { seedling (Yes/ No) }\end{array}$ & 79 & 79 & 65 & 65 & 144 & 72 \\
\hline 32 & $\begin{array}{l}\text { Seed bed preparation is as like as } \\
\text { traditional method (Yes/ No) }\end{array}$ & 93 & 93 & 83 & 83 & 176 & 88 \\
\hline 33 & $\begin{array}{l}\text { SRI method is beneficial because need } \\
\text { less seed, water, manures and fertilizers/ } \\
\text { ultimate benefit cost is less. (need less } \\
\text { seed,less water/benefit cost is less) }\end{array}$ & 97 & 97 & 97 & 97 & 194 & 97 \\
\hline 34 & $\begin{array}{l}\text { There is no difference between SRI and } \\
\text { traditional method of paddy cultivation. } \\
\text { (Yes/ No) }\end{array}$ & 97 & 97 & 70 & 70 & 167 & 83.5 \\
\hline 35 & $\begin{array}{l}\text { Frequent spraying is needed in SRI } \\
\text { method of Paddy cultivation.(True/False) }\end{array}$ & 97 & 97 & 75 & 75 & 172 & 86 \\
\hline 36 & $\begin{array}{l}\text { SRI method requires sound education } \\
\text { (Yes/ No) }\end{array}$ & 98 & 98 & 91 & 91 & 189 & 94.5 \\
\hline 37 & $\begin{array}{l}\text { There are No. of principle to be followed } \\
\text { in SRI (6/8/10 Nos.) }\end{array}$ & 95 & 95 & 76 & 76 & 171 & 85.5 \\
\hline 38 & $\begin{array}{l}\text { People say SRI method of paddy } \\
\text { cultivation gainful (True/False) }\end{array}$ & 96 & 96 & 92 & 92 & 188 & 94 \\
\hline 39 & $\begin{array}{l}\text { SRI method is not alternative to increase } \\
\text { production (True/False) }\end{array}$ & 57 & 57 & 51 & 51 & 108 & 54 \\
\hline 40 & $\begin{array}{l}\text { In SRI method disadvantage is more than } \\
\text { advantage (Yes/No) }\end{array}$ & 90 & 90 & 75 & 75 & 165 & 82.5 \\
\hline
\end{tabular}




\section{Knowledge Index Scores}

\begin{tabular}{|c|c|c|c|}
\hline \multirow[t]{2}{*}{ Category (Knowledge) } & \multicolumn{3}{|l|}{ Scores } \\
\hline & $\begin{array}{l}\text { West Tripura } \\
\text { (100 respondents) }\end{array}$ & $\begin{array}{c}\text { South Tripura } \\
\text { (100 respondents) }\end{array}$ & $\begin{array}{c}\text { Tripura } \\
\text { (200 respondents) }\end{array}$ \\
\hline Low (up to X- ${ }^{-1} / 2 \mathrm{SD}$ ) & Up to 71.5207 & Up to 73.0642 & Up to 72.3011 \\
\hline Medium $\left(X-1 / 2 S D\right.$ to $\left.X+{ }^{1} / 2\right)$ & 71.5207 to 86.8292 & 73.0642 to 87.1857 & 72.3011 to 86.9988 \\
\hline $\operatorname{High}($ above $\mathrm{X}+1 / 2 \mathrm{SD})$ & Above 86.8292 & Above 87.1857 & Above 86.9988 \\
\hline & $\begin{array}{l}\text { Mean: } 79.175 \\
\text { SD : } 15.3085\end{array}$ & $\begin{array}{l}\text { Mean : } 80.125 \\
\text { SD : } 14.1214\end{array}$ & $\begin{array}{l}\text { Mean: } 79.65 \\
\text { SD : } 14.6976\end{array}$ \\
\hline
\end{tabular}

Fig.1 Distribution of respondents based on their level of knowledge

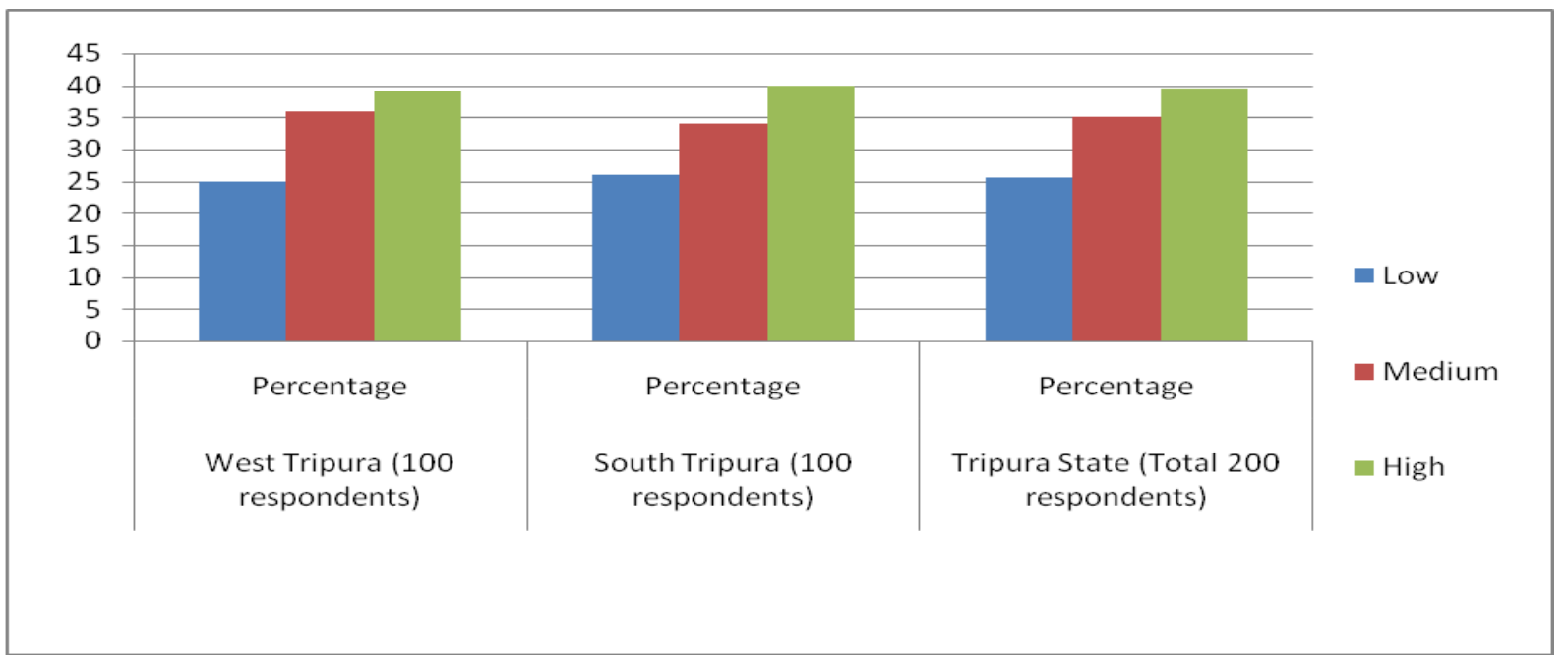

\section{South Tripura}

The Table also indicates that 100 per cent of rice farmers have precise correct knowledge regarding SRI method of cultivation requires (more / less seed).

\section{Tripura}

The Table indicates that 100 per cent of rice farmers have precise knowledge on SRI practices in such vital item as correct knowledge regarding SRI method of cultivation requires (more / less seed).

In Tripura state as a whole a large section of the SRI farmers possessed knowledge high to medium level (39.5\% to $35.0 \%$ ) on system of rice intensification (SRI) technology. Majority of rice farmers were aware of the six principles of SRI like sowing of tender seedling, per hill single seedling, depth of transplanting, water management, weed management and about the benefit of application of bio-fertilizer/ organic manure. This showed that knowledge on SRI technology was mostly percolated to the SRI farmers' level but they had constraint in the adoption of the technology fully due to some other factors like timely availability of skilled labourers, high cost of labour wages, problem of assured irrigation, weed management problem, farm mechanization, high cost of manures and fertilizer, high cost of pesticides- 
insecticides, complicated procedure for obtaining loan from the credit organization, untimely release of loan by the credit organization and lack of support price. The majority of the farmers have obtained high adoption score. The mean adoption score (83.0) obtained by the SRI farmers also revealed the high level of adoption.

\section{References}

Beerannavar, B., 1995. A study on knowledge and adoption of improved dairy management practices by farmers trained by KVK, Hanumanamatti, M.Sc. (Agri) thesis, U.A.S, Dharwad.

Kumar, Mahandra. 1996. Communication behaviour of fish farmers in Tamil Nadu, Ph.D. thesis, CIFE, Mumbai.

Meti, 1998. Technology research, perception, knowledge, adoption and attitude towards agricultural technologies by small and marginal farmers in TBP area Ph.D. thesis, U.A.S., Dharwad.

\section{How to cite this article:}

Dipak Nath and Das, D.K. 2018. Knowledge on SRI (System of Rice Intensification) of Farmers in Tripura, India. Int.J.Curr.Microbiol.App.Sci. 7(03): 3586-3592.

doi: https://doi.org/10.20546/ijcmas.2018.703.412 